\title{
Evidence for Completion of Home Modifications for Decrease in Risk of Falls and Preservation of Autonomy
}

\author{
Hassan Izzeddin Sarsak* \\ Department of Occupational Therapy, Batterjee Medical College, Saudi Arabia \\ *Corresponding author: Hassan Izzeddin Sarsak, Department of Occupational Therapy, Batterjee Medical College, Jeddah, Saudi Arabia
}

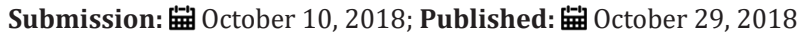

\begin{abstract}
Objectives: To review current literature on home modifications related to decreasing risk of falls and/or impact on autonomy to support best practice methods.

Results: Our review revealed three studies suggesting that for community dwelling older adults aged 65 years and older, a home modification intervention may decrease risk for falls and maintain autonomy.
\end{abstract}

Conclusion: Home modifications are effective and may reduce the risk of falling and maintain autonomy in older adults.

Keywords: Home modification; Risk of fall; Autonomy; Older adults; Activities of daily living; Occupational therapy; Randomized controlled trail

\section{Introduction}

Within the community dwelling population about $1 / 4-1 / 3$ of persons aged 65-79 fall every year. Persons aged $>80$ years have about $1 / 2$ fall every year Nikolaus \& Bach [1]. More than $1 / 2$ of the persons who have experienced a fall will have multiple episodes a year. Falls can result in loss of independence of activities of daily living (ADLs) Pardessus et al. [2]. Home modifications are utilized by occupational therapists (OTs) to provide environmental changes to remove hazards which can cause falls [3,4]. Effectiveness of home modifications has been debated. Risk for falls is an imbalance between the patient's autonomy and environmental hazards [2-5]. The purpose of this study was to review current literature on home modifications related to decreasing risk of falls and/or impact on autonomy to support best practice methods. For the purpose of this study, we created a clinical/research PICO question (Population, Intervention, Comparison, and Outcome), a key to evidence-based decision [6]. The PICO formed for our study is as follows:

(P): For community dwelling older adults aged 65 years and older
(I): Does a home modification intervention
(C): No comparison
(0): Decrease risk for falls and/or impact autonomy?

\section{Methods}

\section{Review of literature and search strategy}

A research has been made in the following databases: Ovid, CINAHL, and PubMed. Keywords and Search items used to search articles for our study were home modification, risk of fall, autonomy, older adults, activities of daily living, occupational therapy, randomized controlled trail. By combining the search results, we found articles on home modifications for decrease in risk of falls and preservation of autonomy. Based on the format of PICO question, three most relevant articles were selected for our study. Studies cited in the reference of the three articles along with other articles were also used to collect important information. After all, the strongest evidence-based article was chosen based on level of evidence and significance level to highlight and confirm our results and conclusions.

\section{Results}

The three selected articles were related to the effectiveness of home modifications for decrease in risk of falls and preservation of autonomy. All articles were related to our PICO question. A summary of the three articles in relation to our PICO is presented (Table 1). 
Table 1: A summary of Reviewed Articles in Relation to our PICO.

\begin{tabular}{|c|c|c|}
\hline Article & Our PICO & Relate to PICO (Article Summary) \\
\hline \multirow{5}{*}{ Cumming et al. [5] } & $\begin{array}{l}\text { (P): For community dwelling older adults aged } 65 \text { years } \\
\text { and older }\end{array}$ & (P): For community dwelling older adults with a risk of fall \\
\hline & (I): Does a home modification intervention & (I): Home modification intervention \\
\hline & \multirow{2}{*}{ (C): No comparison } & (C): No comparison \\
\hline & & (0): Decrease the risk of falls \\
\hline & (0): Decrease risk for falls and/or impact autonomy? & *No information provided about autonomy \\
\hline \multirow{4}{*}{ Pardesseus et al. [2] } & & (P): For community dwelling older adults with a risk of fall \\
\hline & & (I): Home modification intervention \\
\hline & & (C): No comparison \\
\hline & & $\begin{array}{l}\text { (0): did not decrease the risk of falls however, autonomy was } \\
\text { preserved }\end{array}$ \\
\hline \multirow{5}{*}{ Nikolaus \& Bach [1] } & & (P): For community dwelling older adults with a risk of fall \\
\hline & & (I): Home modification intervention \\
\hline & & (C): No comparison \\
\hline & & (0): Decrease the risk of falls \\
\hline & & *No information provided about autonomy \\
\hline
\end{tabular}

\section{Discussion}

Cumming et al. [5] which examined the effectiveness of home modifications for decrease in risk of falls was selected as the strongest evidence-based article. Based on the hierarchy of levels of evidence in evidence-based practice, this study was a level II (Evidence obtained from at least one well designed RCT) [7]. They used a large sample size of 530 subjects. The intervention group $(n=264)$ received home visits from an occupational therapist (OT), provided with a list of recommended home modifications, and further home visits were also provided if needed. Phone calls were made to encourage compliance with modifications, and a completion of monthly falls calendar was conducted. In the control group $(n=266)$, no home visits were provided, and a completion of monthly falls calendar was conducted. In this study, the number of falls between intervention group (226) and control group (324) was not statistically significant. For subjects who experienced $>1$ fall in follow up period there was a reduction in risk of falling by $19 \%(\mathrm{p}=.05)$. For subjects with a history of falls, there was a reduction in risk of falling in the intervention group by $36 \%(p=.001)$. For subjects with no history of falls the reduction in risk of falling was not significant. Evidence for decrease in risk of falls was supported by Cumming et al. [5]. In addition, evidence for preservation of autonomy was supported by Pardessus et al. [2]. Home modifications can be effective for decreasing the risk of falls and maintaining autonomy amongst community dwelling older adults. Thus, the following plan has been developed in our study and can be executed in clinics to ensure implementation of recommendations on home modifications for individuals with a history of falls who plan to return home (Table 2).

Table 2: A summary of recommendations, plan, and audit tool.

\begin{tabular}{|c|c|c|c|c|}
\hline Recommendation & Implementation Plan & Criteria & Audit Method & Compliance Plan \\
\hline $\begin{array}{l}\text { 1. Occupational Therapy } \\
\text { staff will be presented with } \\
\text { evidence to support home } \\
\text { modifications to decrease risk } \\
\text { of falls. }\end{array}$ & $\begin{array}{l}\text { Schedule a formal in } \\
\text { service to be provided to } \\
\text { all occupational therapy } \\
\text { team members }\end{array}$ & $\begin{array}{l}100 \% \text { of occupational } \\
\text { therapy team mem- } \\
\text { bers will attend the in } \\
\text { service. }\end{array}$ & $\begin{array}{l}\text { A sign-in list will be provided } \\
\text { to document attendance. Also a } \\
\text { certificate of attendance will be } \\
\text { provided to participating staff } \\
\text { and a copy of certificate will be } \\
\text { kept in staff personnel file. }\end{array}$ & $\begin{array}{l}\text { The OT manager will check } \\
\text { the sign-in sheet for full } \\
\text { attendance. If staff has not } \\
\text { attended in service within } 1 \\
\text { month he will be subject to } \\
\text { formal write-up }\end{array}$ \\
\hline $\begin{array}{l}\text { 2. New staff members will } \\
\text { receive home modification in } \\
\text { service as part of orientation } \\
\text { process }\end{array}$ & $\begin{array}{l}\text { OT manager will ensure } \\
\text { information supporting } \\
\text { home modifications will } \\
\text { be provided to new staff } \\
\text { during orientation }\end{array}$ & $\begin{array}{l}\text { New staff will receive } \\
\text { home modification } \\
\text { information within } 3 \\
\text { days of hire }\end{array}$ & $\begin{array}{l}\text { OT manager will review ori- } \\
\text { entation check-list to ensure } \\
\text { home modification in service } \\
\text { task has been completed }\end{array}$ & $\begin{array}{l}\text { The OT manager will } \\
\text { inform the new staff and } \\
\text { the orienting staff member } \\
\text { the pending in service on } \\
\text { home modification and a } \\
\text { grace period of } 7 \text { days will } \\
\text { be allotted within which the } \\
\text { task has to be fulfilled }\end{array}$ \\
\hline
\end{tabular}




\begin{tabular}{|c|c|c|c|c|}
\hline $\begin{array}{l}\text { 3. Therapists will demonstrate } \\
\text { proficiency in home modifi- } \\
\text { cations. }\end{array}$ & $\begin{array}{l}\text { The proficiency of } \\
\text { the therapists will be } \\
\text { assessed by the OT man- } \\
\text { ager by completion of } \\
\text { one home visit followed } \\
\text { by discussion of the } \\
\text { recommendations with } \\
\text { the OT manager. }\end{array}$ & $\begin{array}{l}\text { The therapists demon- } \\
\text { strating } 90 \% \text { agreement } \\
\text { of recommended home } \\
\text { modifications with the } \\
\text { OT manager will com- } \\
\text { plete home evaluations. }\end{array}$ & $\begin{array}{l}\text { The OT manager will supervise } \\
\text { the home visit with the treating } \\
\text { therapist to ensure proficiency. }\end{array}$ & $\begin{array}{l}\text { The therapist who has } \\
\text { not demonstrated profi- } \\
\text { ciency will receive further } \\
\text { education regarding home } \\
\text { modification techniques }\end{array}$ \\
\hline $\begin{array}{l}\text { 4. The } 0 T \text { manager will assign } \\
\text { a lead therapist to train and } \\
\text { supervise new staff/therapists. }\end{array}$ & $\begin{array}{l}\text { The OT manager } \\
\text { distinguishes the lead } \\
\text { therapist based on the } \\
\text { proficiency in home } \\
\text { modifications to train } \\
\text { and supervise new staff/ } \\
\text { therapist. }\end{array}$ & $\begin{array}{l}\text { The lead therapist will } \\
\text { ensure that } 100 \% \text { of the } \\
\text { new staff/therapists are } \\
\text { trained. }\end{array}$ & $\begin{array}{l}\text { Based on the reports provided } \\
\text { by the lead therapist, the OT } \\
\text { manager will document the } \\
\text { completion of training to the } \\
\text { new staff in their personnel file. }\end{array}$ & $\begin{array}{l}\text { The OT manager will make } \\
\text { sure that the lead therapist } \\
\text { provides training to } 100 \% \\
\text { of the new staff. If training } \\
\text { was not provided, the lead } \\
\text { therapist is given an exten- } \\
\text { sion of } 2 \text { weeks to train staff. } \\
\text { In the event that training is } \\
\text { not provided within exten- } \\
\text { sion time a verbal warning } \\
\text { will be issued to the lead } \\
\text { therapist }\end{array}$ \\
\hline $\begin{array}{l}\text { 5. The new staff on the home } \\
\text { evaluation team observes and } \\
\text { completes home evaluation } \\
\text { checklist as the lead therapist } \\
\text { carries out the home visit. }\end{array}$ & $\begin{array}{l}\text { At the time of home } \\
\text { evaluation both the lead } \\
\text { therapist and the new } \\
\text { staff will complete the } \\
\text { checklist. }\end{array}$ & $\begin{array}{l}\text { The new staff will } \\
\text { demonstrate } 90 \% \\
\text { agreement with the lead } \\
\text { therapist on recommen- } \\
\text { dations within } 3 \text { home } \\
\text { evaluations. }\end{array}$ & $\begin{array}{l}\text { The recommendation by the } \\
\text { new staff will be compared to } \\
\text { those of the lead therapist at } \\
\text { the end of } 3 \text { home evaluations. }\end{array}$ & $\begin{array}{l}\text { If agreement is }<90 \% \text {, the } \\
\text { new staff will be allowed } \\
3 \text { more home visits under } \\
\text { the supervision of the lead } \\
\text { therapist. }\end{array}$ \\
\hline $\begin{array}{l}\text { 6. Patients with a history of } \\
\text { falls and within the eligibility } \\
\text { criteria will be identified by } \\
\text { the lead therapist for comple- } \\
\text { tion of a home evaluation. }\end{array}$ & $\begin{array}{l}\text { Patients with upcom- } \\
\text { ing discharge within } \\
2 \text { weeks having safety } \\
\text { issues will be identified } \\
\text { by the treating therapist } \\
\text { for completion of home } \\
\text { evaluation. }\end{array}$ & $\begin{array}{l}100 \% \text { of the patients } \\
\text { identified will be } \\
\text { enlisted to receive home } \\
\text { evaluations }\end{array}$ & $\begin{array}{l}\text { The OT manager will ensure } \\
\text { that all patients with potential } \\
\text { safety risks will be enlisted for } \\
\text { home evaluations. }\end{array}$ & $\begin{array}{l}\text { Patients not enlisted for } \\
\text { home evaluations will be } \\
\text { included. }\end{array}$ \\
\hline $\begin{array}{l}\text { 7. All patients scheduled for } \\
\text { home evaluations will receive } \\
\text { them. }\end{array}$ & $\begin{array}{l}\text { The home evaluation } \\
\text { therapist will complete } \\
\text { the home evaluation of } \\
\text { all identified patients. }\end{array}$ & $\begin{array}{l}100 \% \text { of the identified } \\
\text { patients will receive } \\
\text { home evaluation } \\
\text { within } 1 \text { week of their } \\
\text { discharge. }\end{array}$ & $\begin{array}{l}\text { The OT manager ensures that } \\
\text { all the identified patients } \\
\text { receive home evaluation by } \\
\text { reviewing documentation }\end{array}$ & $\begin{array}{l}\text { The therapist will be allot- } \\
\text { ted } 2 \text { extra days to complete } \\
\text { all scheduled evaluations } \\
\text { or will receive a verbal } \\
\text { warning. }\end{array}$ \\
\hline $\begin{array}{l}\text { 8. All patients who have re- } \\
\text { ceived a home evaluation will } \\
\text { be provided with a completed } \\
\text { home evaluation form with the } \\
\text { recommendations. }\end{array}$ & $\begin{array}{l}\text { After the home evalu- } \\
\text { ation is completed the } \\
\text { therapist will provide the } \\
\text { patient with the complet- } \\
\text { ed home evaluation form. }\end{array}$ & $\begin{array}{l}100 \% \text { of the patients } \\
\text { who receive home eval- } \\
\text { uations will be provided } \\
\text { with the completed } \\
\text { home evaluation form. }\end{array}$ & $\begin{array}{l}\text { The OT manager will review } \\
\text { the patient's chart to ensure } \\
\text { presence of completed home } \\
\text { evaluation form. }\end{array}$ & $\begin{array}{l}\text { If a home evaluation form is } \\
\text { not completed and placed } \\
\text { into the patients chart the } \\
\text { therapist who completed } \\
\text { the evaluation will be ver- } \\
\text { bally warned. }\end{array}$ \\
\hline $\begin{array}{l}\text { 9. A follow-up phone call } \\
\text { to check for compliance of } \\
\text { recommendations will be } \\
\text { completed for all patients } \\
\text { who have received a home } \\
\text { evaluation. }\end{array}$ & $\begin{array}{l}\text { The OT manager com- } \\
\text { pletes a follow-up phone } \\
\text { call to the patient to } \\
\text { check compliance with } \\
\text { the modification recom- } \\
\text { mendations. }\end{array}$ & $\begin{array}{l}\text { Calls are made to } 100 \% \\
\text { of the patients after } 2 \\
\text { weeks of discharge. }\end{array}$ & $\begin{array}{l}\text { The OT manager will document } \\
\text { follow up phone calls within } \\
\text { the patient's soft chart. }\end{array}$ & $\begin{array}{l}\text { The OT manager will review } \\
\text { all discharged patients, who } \\
\text { received a home evaluation, } \\
\text { chart monthly to ensure } \\
\text { phone calls were completed. }\end{array}$ \\
\hline
\end{tabular}

\section{Conclusion}

Our review suggested that home modifications are effective and may reduce the risk of falling and preserve autonomy in older adults. Thus, clinical guidelines, recommendations, a plan and audit tool have been created in our study to implement home modifications in clinics. The clinical guidelines for recommended intervention, the plan, and the audit tool recommend therapists to apply home modifications with older adults who are at risk of falls.

\section{Funding details}

No funding was required.

\section{Acknowledgement}

None.

\section{Conflict of interest}

Author declares that there is no conflict of interest.

\section{References}

1. Nikolaus T, Bach M (2003) Preventing falls in community-dwelling frail older people using a Home Intervention Team (HIT): Results from the randomized falls-HIT trial. Journal of the American Geriatrics Society 51(3): 300-305. 
2. Pardessus V, Puisieux F, Di Pompeo C, Gaudefroy C, Thevenon A, et al. (2002) Benefits of home visits for fall and autonomy in the elderly: A randomized trial study. American Journal of Physical Medicine \& Rehabilitation 81(4): 247-252.

3. Rao SS (2005) Prevention of falls in older patients. American Family Physician 72(1): 81-88.

4. Wyman JF, Croghan CF, Nachreiner NM, Gross CR, Stock HH, et al. (2007) Effectiveness of education and individualized counseling in reducing hazards in community-dwelling older women. Journal of the American Geriatrics Society 55(10): 1548-1556.
5. Cumming RG, Thomas M, Szonyi G, Salkeld G, O’Neill E, et al. (1999) Home visits by an occupational therapist for assessment and modification of environmental hazards: A randomized trial of falls prevention. Journal of the American Geriatrics Society 47(12): 1397-1402.

6. Richardson WS, Wilson MC, Nishikawa J, Hayward RS (1995) The wellbuilt clinical question: A key to evidence-based decision. ACP Journal Club 123(3): A12-A13.

7. Hughes I (2006) Action research in healthcare: What is the evidence? ALAR Journal 11(1): 29-39.
Creative Commons Attribution 4.0 International License

For possible submissions Click Here

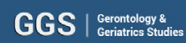

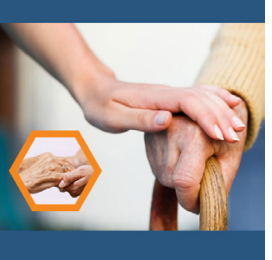

\section{Gerontology \& Geriatrics Studies}

\section{Benefits of Publishing with us}

- High-level peer review and editorial services

- Freely accessible online immediately upon publication

- Authors retain the copyright to their work

- Licensing it under a Creative Commons license

- Visibility through different online platforms 